\title{
THE APPROXIMATE ESTIMATION OF THE EXPIRATION DATE OF FROZEN FOOD
}

\author{
D. Sinat-Radchenko, M. Maslikov \\ National University of Food Technologies
}

\begin{tabular}{|c|c|}
\hline Key words: & ABSTRACT \\
\hline $\begin{array}{l}\text { Frozen food } \\
\text { Storage time } \\
\text { Storage temperature } \\
\text { Storage time ratio }\end{array}$ & $\begin{array}{l}\text { Modern refrigeration technologies for food products invol- } \\
\text { ve the creation of a "cold chain" to provide a continuous effect } \\
\text { of cold on the product from production to storage. During the } \\
\text { design of this chain it is necessary for each of its components }\end{array}$ \\
\hline $\begin{array}{l}\quad \text { Article history: } \\
\text { Received } 02.03 .2018 \\
\text { Received in revised form } \\
\text { 20.03.2018 } \\
\text { Accepted } 05.04 .2018 \\
\end{array}$ & $\begin{array}{l}\text { (procurement refrigerators, industrial refrigerators, distribution } \\
\text { refrigerators, transport refrigerators, trade refrigerators, domes- } \\
\text { tic refrigerators and refrigeration transport) to provide storage } \\
\text { conditions which would ensure the acceptable quality of the } \\
\text { product with minimal losses at a minimum cost of money. The }\end{array}$ \\
\hline $\begin{array}{l}\text { Corresponding author: } \\
\text { M. Maslikov } \\
\text { E-mail: } \\
\text { npnuht@ukr.net }\end{array}$ & $\begin{array}{l}\text { most important regulated parameter for frozen food storing is } \\
\text { the storage temperature }\left(t_{\mathrm{st}}\right) \text {. It is known that its decreasing } \\
\text { leads to the increasing of the expiration date }\left(\tau_{\mathrm{st}}\right) \text {, but decrea- } \\
\text { sing of this temperature to eutectic }\left(-70 \ldots-80^{\circ} \mathrm{C}\right) \text { is inappro- } \\
\text { priate, when only the strongest-bound water in proteins stays } \\
\text { unfrozen, because of the large energy consumption for freezing, } \\
\text { further storage and defrosting of the product. The dependences } \\
\text { between temperature and possible expiration date are complex } \\
\text { and different for different food products because of the various } \\
\text { processes that occur. The question about dependence of the expi- } \\
\text { ration date on storage temperature with still preserving a satisfac- } \\
\text { tory consumer product in world practice is known as "Time - } \\
\text { Temperature Tolerance problem" or "T - T T problem". } \\
\text { Existing methods of determining the terms and tempera- } \\
\text { tures of food storage are analyzed in this article. Simplified } \\
\text { formulas for the approximate estimation of the expiration date } \\
\text { of frozen food products, determination of the ratio of these } \\
\text { terms at different storage temperatures, and the choice of opti- } \\
\text { mal storage temperature during the given period are proposed. } \\
\text { These formulas can be used during refrigerators operation and } \\
\text { designing of the refrigeration chain for food products. Examp- } \\
\text { les of these calculations are given. }\end{array}$ \\
\hline
\end{tabular}

DOI: $10.24263 / 2225-2924-2018-24-2-17$

\section{НАБЛИЖЕНА ОЦІНКА ТЕРМІНІВ ЗБЕРІГАННЯ ЗАМОРОЖЕНИХ ХАРЧОВИХ ПРОДУКТІВ}

\author{
Д.С. Сінат-Радченко, М.М. Масліков \\ Національний університет харчових технологій
}

Сучасні технології холодильного оброблення харчових продуктів передбачають створення так званого холодильного ланщюга, щэоб забезпечувати без- 
перервний вплив холоду на продукт від вироблення до зберігання у споживача. Під час проектування такого ланиюга необхідно для кожної його ланки (заготівельні, виробничі, розподільчі, транспортні, торговельні, побутові холодильники, а також холодильний транспорт) передбачити умови зберігання, які б забезпечили прийнятну якість продукту з мінімальними втратами за мінімальних затрат коштів. Найважливішим регульованим параметром під час зберігання заморожених харчових продуктів є температура зберігання $\left(t_{\text {зб}}\right)$. Відомо, щео ї̈ зниження приводить до зростання терміну зберігання $\left(\tau_{3 \sigma}\right)$, але знижувати $t_{3 б}$ до евтектичної $\left(-70 \ldots-80^{\circ} \mathrm{C}\right)$, коли невимороженою лишається лише найміџніше зв 'язана з білками вода, недочільно через занадто великі енерговитрати на заморожування, подальше зберігання та розморожування продукту. Залежності між температурою та можливим терміном зберігання складні і різні для різних харчових продуктів через різні процеси, що у них відбуваються. Питання про залежність терміну зберігання від температури за збереження прийнятної якості продукту у світовій практиці називають проблемою трьох T: Tiте - Teтреrature Tolerance.

У статті проаналізовано існуючі способи визначення термінів і температур зберігання харчових продуктів, запропоновано спрощені формули для наближеного оцінювання термінів зберігання заморожених харчових продуктів, визначення співвідношення иих термінів при різних температурах зберігання, вибору оптимальної температури зберігання за заданого його терміну. Ці формули можуть бути використані під час експлуатації холодильників і проектування холодильного ланиюга для харчових продуктів Наведено приклади зазначених розрахунків.

Ключові слова: заморожені продукти, температура зберігання, термін зберігання, співвідношення термінів.

Постановка проблеми. Холодильне зберігання є найпоширенішим способом зберігання харчових продуктів. Зараз, крім продуктів тваринництва, широко заморожують овочеві суміші, плоди і ягоди, напівфабрикати і кулінарні вироби. Швидкозаморожені продукти та напівфабрикати скорочують втрати найважливіших біологічно цінних компонентів і суттєво зменшують витрати домашньої праці. Сучасні технології холодильного оброблення харчових продуктів передбачають створення холодильного ланцюга - забезпечувати безперервний вплив холоду на продукт від вироблення до зберігання у споживача. Під час проектування такого ланцюга необхідно для кожної його ланки (заготівельні, виробничі, транспортні, торговельні, побутові холодильники, а також холодильний транспорт) передбачати умови зберігання, які б забезпечили прийнятну якість продукту з мінімальними втратами за мінімальних вкладень коштів.

Аналіз останніх досліджень і публікацій. Можливий термін зберігання продукту $\left(\tau_{3 \sigma}\right)$ залежить від індивідуальних властивостей продукту та умов його зберігання. Серед численних параметрів, що визначають умови зберігання, найчастіше розглядають лише температуру зберігання $\left(t_{30}\right)$, відносну вологість повітря $\left(\varphi_{\text {пов }}\right)$ і швидкість його руху $\left(w_{\text {пов}}\right)$. Регульованим параметром $\epsilon$ насамперед $t_{36}[1]$. 
За сталого температурного коефіцієнта швидкість реакцій, що спричиняють небажані зміни продуктів, наближено може бути представлена у вигляді експоненціальної функції [2]. Ще у 1949 р. Д.Г. Рютов запропонував формулу для терміну зберігання:

$$
\tau_{3 \sigma}=a \cdot 10^{-c t_{3 \sigma}},
$$

де $\tau_{3 б}$ - термін зберігання, міс.; $t_{3 б}$ - температура зберігання, ${ }^{\circ} \mathrm{C}$; $a$ та $c-$ коефіцієнти, що залежать від властивостей харчових продуктів. Для всіх видів м'яса і риби $c=0,05$, а для вершкового масла $c=0,036$. Для яловичини $\mathrm{i}$ баранини $a=2,15$, для свинини і нежирної риби $-1,78$, для курей $-1,58$, для гусей, кролів і жирної риби - 1,26, а для вершкового масла - 2,85 [2].

3 часом діапазон використовуваних температур зберігання змінився від $-6 \ldots-20^{\circ} \mathrm{C}$ до $-12 \ldots-30^{\circ} \mathrm{C}$, у зв'язку з чим змінилися і значення рекомендованих термінів зберігання при різних температурах для конкретних продуктів.

Суттєвий вплив на стійкість заморожених продуктів має льодоутворення [3]. При більш низьких $t_{3 б}$ зростає частка вимороженої води $(\omega)$ у продуктах (табл. 1). Вважається, що повністю вільна вода у продуктах вимерзає при температурі, близькій до евтектичної температури розчинених у ній речовин. Проте можливе вивільнення зв'язаної води. Так, під час заморожування сиру «Голандський» до $-20^{\circ} \mathrm{C}$ залишається невимороженою $18 \%$ води $(17,7 \%$ від загального вологовмісту становить зв'язана вода у структурі білків), тобто вільна вода практично повністю вимерзає. За подальшого зниження температури частина зв'язаної води переходить до вільного стану і кристалізується. Слабковиражений евтектичний стан продукту спостерігається при температурі близько $-70^{\circ} \mathrm{C}$. У точці евтектики залишається невимороженою близько $7 \%$ найбільш міцно зв'язаної з білками води. При температурах $-70 \ldots-80^{\circ} \mathrm{C}$ у продукті некристалізованою залишається лише найбільш міцно хімічно зв'язана волога білків [6], проте заморожування до такої температури та холодильне зберігання при ній не проводять через занадто великі енерговитрати на заморожування, подальше зберігання та розморожування продукту.

Таблиия 1. Частка вимороженої води при різних температурах [3]

\begin{tabular}{|c|c|c|c|c|c|}
\hline \multirow{2}{*}{ Продукт } & \multicolumn{5}{|c|}{ Температура продукту, ${ }^{\circ} \mathrm{C}$} \\
\cline { 2 - 6 } & -10 & -15 & -20 & -25 & -30 \\
\hline Яловичина 1-ї категорії & 0,866 & 0,901 & 0,919 & 0,931 & 0,938 \\
\hline Сир кисломолочний & 0,868 & 0,902 & 0,920 & 0,931 & 0,939 \\
\hline
\end{tabular}

У літературних джерелах дані про залежність терміну зберігання від температури можуть відрізнятися, тому зіставлюваних дослідних даних поки що недостатньо. Через невелику точність дані про терміни зберігання зазвичай подаються як ціле число місяців. Крім того, режими і терміни зберігання завжди встановлюють виходячи 3 того, що на зберігання закладаються продукти високої якості [4; 5], а в умовах холодильного ланцюга це не завжди так.

Крім терміну й температури зберігання, важливим $є$ питання збереження якості продукту після закінчення зберігання. Якість може бути відмінною, дуже доброю і задовільною. Зрозуміло, що краща якість за однакової $t_{3 б}$ 
спостерігається для меншого $\tau_{3 б}$. Питання про залежність терміну зберігання від температури за збереження прийнятної якості продукту у світовій практиці називають проблемою трьох Т [2]: «Time - Temperature Tolerance». Ця проблема $\epsilon$ важливою у проектуванні холодильного ланцюга для продуктів, а також у визначенні оптимальних (з мінімальними затратами коштів) параметрів холодильного зберігання. Також під час вибору температури зберігання слід пам'ятати, що ії зниження сприяе збільшенню терміну зберігання, проте водночас призводить до збільшення витрат електроенергії холодильною установкою.

Найчастіше для зберігання заморожених продуктів і напівфабрикатів використовується температура зберігання $t_{30}=-18^{\circ} \mathrm{C}$. Саме для цієї температури опубліковано найбільше даних про терміни зберігання. Слід зазначити, що індивідуальні властивості заморожених продуктів менше впливають на процес зберігання, ніж для охолоджених.

Математичне моделювання процесів зберігання поряд з експериментальними методами широко застосовується у світовій практиці, проте харчові продукти $є$ досить складним об'єктом моделювання через велику кількість взаємопов'язаних процесів, що відбуваються в них під час зберігання (хімічних, фізичних, мікробіологічних та ін.), причому для різних продуктів вирішальний вплив на якість чинять різні процеси [7]. Складність об'єкта моделювання, спричиняє складність і громіздкість моделі, велику кількість наближень, дослідних коефіцієнтів та пов'язані з цим похибки. Тому виникає практична потреба у простіших наближених методах оцінювання термінів зберігання.

Мета дослідження: сформулювати прості залежності, що можуть бути використані для розв'язання практичних завдань холодильної технології, насамперед визначення терміну зберігання замороженого продукту при певній температурі за збереження прийнятної якості продукту (у тому числі за змінної температури зберігання) та вибору оптимальної температури зберігання при потрібному терміні зберігання.

Викладення основних результатів дослідження. Експоненціальні функції $є$ частиною більш загальних показникових функцій. Тому рівняння (1) можна записати, як:

$$
\tau_{36}=a b^{-t_{3 \sigma}},
$$

де $b=10^{-\mathrm{c}}$. Значення коефіцієнтів $a$ та $b$ залежить від виду продукту.

У напівлогарифмічних координатах $\lg \tau_{36}-t_{36}$ залежність (2) виглядає як пряма лінія. Тангенс кута нахилу цієї прямої до осі температур:

$$
\operatorname{tg} \phi=\frac{\lg \frac{\tau_{362}}{\tau_{3 б 1}}}{t_{3 б 2}-t_{3 б 1}}=\lg b .
$$

Чим більший нахил прямої до осі температур, тим більша величина $b .3$ формули (2):

$$
a=\frac{\tau_{3 \sigma}}{b^{-t_{3 \sigma}}} .
$$


Чим більша відстань прямої від осі температур за даної температури зберігання, тим більше значення $a$. Значення коефіцієнтів $a$ та $b$ для деяких заморожених продуктів наведені у табл. 2. Також у ній наведені значення термінів зберігання при різних температурах $[1 ; 2 ; 4 ; 5]$. У дужках наведені значення, розраховані за формулою (2).

\section{Таблиця 2. Терміни зберігання деяких продуктів при різних температурах}

\begin{tabular}{|c|c|c|c|c|c|c|c|c|}
\hline \multirow{2}{*}{$\begin{array}{l}\text { № } \\
\text { пор. }\end{array}$} & \multirow{2}{*}{ Продукт } & \multirow{2}{*}{$a$} & \multirow[t]{2}{*}{$b$} & \multicolumn{5}{|c|}{$\begin{array}{c}\text { Термін зберігання, міс, при температурі зберігання, } \\
{ }^{\circ} \mathrm{C}\end{array}$} \\
\hline & & & & -12 & -15 & -18 & \begin{tabular}{|l|}
-20 \\
\end{tabular} & -25 \\
\hline 1 & $\begin{array}{l}\text { Яловичина в } \\
\text { напівтушах і } \\
\text { четвертинах }\end{array}$ & 3,784 & 1,06437 & $8(8,00)$ & $-(9,65)$ & $12(11,63)$ & $14(13,18)$ & $18(18,00)$ \\
\hline 2 & $\begin{array}{c}\text { Свинина в } \\
\text { напівтушах, } \\
\text { нежирна риба }\end{array}$ & 0,8344 & 1,11253 & $3(3,00)$ & $-(4,13)$ & $6(5,69)$ & $7(7,04)$ & $12(12,00)$ \\
\hline 3 & $\begin{array}{c}\text { Зелений } \\
\text { горошок, } \\
\text { полуниці }\end{array}$ & 0,6637 & 1,16147 & $4(4,00)$ & $-(6,27)$ & $11(9,72)$ & $16(13,25)$ & $28(28,00)$ \\
\hline 4 & Гуси, качки & 1,572 & 1,08092 & $4(4,00)$ & $5(5,05)$ & $7(6,38)$ & $-(7,54)$ & $11(11,00)$ \\
\hline 5 & $\begin{array}{c}\text { Солодковершкове } \\
\text { несолоне масло } \\
\text { в монолітах }\end{array}$ & 5,062 & 1,04912 & $9(9,00)$ & $10(10,39)$ & $12(12,00)$ & $-(13,21)$ & $-(16,79)$ \\
\hline
\end{tabular}

Наприклад, для свинини при температурі зберігання $-12^{\circ} \mathrm{C}$ термін зберігання становить 3 міс., а при температурі зберігання $-25^{\circ} \mathrm{C}-12$ міс. Тоді:

$$
\begin{gathered}
\operatorname{tg} \phi=\lg b=\frac{\lg (12 / 3)}{25-12}=0,04631 ; \\
b=10^{0,04631}=1,11253 ; \\
a=\frac{3}{1,11253^{-(-12)}}=\frac{12}{1,11253^{-(-25)}}=0,8344 .
\end{gathered}
$$

Можливий запис показникової функції у такому вигляді:

$$
\tau_{3 \overline{0}}=\exp \left(\ln a-\mathrm{t}_{3 \sigma} \cdot \ln b\right)
$$

Наприклад, для $t_{30}=-18^{\circ} \mathrm{C}$ одержимо $\tau_{36}=5,69$ міс.

Лінія залежності $\lg \tau_{3 б}=\mathrm{f}\left(t_{3 \sigma}\right)$ іноді відхиляється від прямої, утворюючи невелику опуклість, спрямовану вгору. Тоді розрахункове значення $\tau_{30}$ буде трохи меншим, ніж рекомендоване (в запас).

Для визначення коефіцієнта $b$ потрібні значення $\tau_{3 б}$ хоча $б$ для двох $t_{3 б}$. Якщо значення $\tau_{3 \sigma} €$ лише для однієї $t_{30}$., то можна взяти середнє арифметичне значення $b$ декількох близьких за складом і властивостями продуктів (це суб'єктивно і наближено), а потім визначити $a$ за формулою (4).

Співвідношення між термінами зберігання при двох різних температурах:

$$
n=\frac{\tau_{362}}{\tau_{361}}=b^{t_{561}-t_{362}} .
$$


Наприклад, для свинини:

$$
n=\frac{\tau_{36}^{-25^{\circ} \mathrm{C}}}{\tau_{3 \overline{0}}^{-12^{\circ} \mathrm{C}}}=1,11253^{-12-(-25)}=4,0 .
$$

Співвідношення (6) може бути корисним для наближеної оцінки можливого терміну зберігання продукту у разі зберігання при температурі, що відрізняється від наведеної у довідниках та інструкціях.

На різних стадіях холодильного ланцюга (заготівельні, виробничі, розподільчі, транспортні, торговельні, побутові холодильники, а також холодильний транспорт) температура зберігання продукту може змінюватись. У таких випадках має виконуватись співвідношення:

$$
\sum_{i} \frac{\tau_{i}}{\tau_{3 б . i}} \leq 1
$$

де $\tau_{i}-$ тривалість перебування продукту при температурі $t_{i} ; \tau_{3 \sigma . i}-$ термін зберігання продукту при температурі $t_{i}$.

Наприклад, коли свинина зберігалася при $t_{3 б .1}=-25^{\circ} \mathrm{C}\left(\tau_{3 б .1}=12\right.$ міс.) впродовж 8 місяців, потім при температурі $t_{3 \sigma .2}=-18^{\circ} \mathrm{C}\left(\tau_{3 \sigma .2}=6\right.$ міс.) впродовж одного місяця, а потім потрапляє до камери $3 t_{36.3}=-12^{\circ} \mathrm{C}\left(\tau_{36.3}=6\right.$ міс.), то вона може зберігатись у ній не більше ніж 0,5 міс, бо

$$
1-\frac{8}{12}-\frac{1}{6}=\frac{1}{6}, \text { звідки } \tau_{36.3}=\frac{1}{6} \cdot 3=0,5 \text { міс. }
$$

Слід пам'ятати, що харчові продукти не можна заморожувати повторно, а значні коливання температури продукту впродовж зберігання й транспортування можуть призвести до перекристалізації вологи, пошкодження тканин продукту та значного погіршення його якості після зберігання.

Коли для конкретного продукту відомий потрібний термін зберігання $\tau_{3 б}$ (3 вимог логістики, ситуації на ринку тощо), з рівняння (2) можна визначити максимальну температуру зберігання, що може підтримуватись у холодильній камері:

$$
t_{3 \overline{0}}^{\max }=\frac{\left(\lg a-\lg \tau_{3 \bar{\sigma}}\right)}{\lg b} .
$$

Наприклад, якщо потрібно зберігати свинину впродовж 7 місяців, то

$$
t_{3 \overline{6}}^{\max }=\frac{(\lg 0,8344-\lg 7)}{\lg 1,11253}=-20^{\circ} \mathrm{C} .
$$

Слід враховувати, що термін зберігання для отримання продукту задовільної якості значно довший, ніж для продукту відмінної якості. Наприклад, за даними [2] для нежирної риби при $t_{36}=-18^{\circ} \mathrm{C}$ співвідношення цих термінів становить близько 3.

Ми детально розглянули приклади, що стосуються зберігання свинини. Але аналогічні закономірності зберігання спостерігаються і для інших заморожених продуктів рослинного й тваринного походження. 


\section{Висновки}

Запропоновані спрощені формули, що можуть бути використані під час експлуатації холодильників і проектування холодильного ланцюга для харчових продуктів, зокрема для:

- спрощеної оцінки можливого терміну зберігання заморожених продуктів рослинного й тваринного походження в інтервалі температур $-10 \ldots-25^{\circ} \mathrm{C}$;

- розрахунку співвідношення термінів холодильного зберігання й транспортування при різних температурах продукту;

- вибору оптимальної температури зберігання при потрібному терміні зберігання продукту.

\section{Лiтература}

1. Масліков М.М. Холодильна технологія харчових продуктів. Навч. посіб. / М.М. Масліков. - Київ : НУХТ, 2007. - 335 с.

2. Консервирование пищевых продуктов холодом (теплофизические основы) / И.А. Рогов, В.Е. Куцакова, В.И. Филиппов, С.В. Фролов. — Москва : Колос-С, 1999. — 176 с.

3. Сінат-Радченко Д.Є. Оцінка вмісту вимороженої води в продуктах м'ясо-молочної промисловості / Д.С. Сінат-Радченко, М.М. Масліков, М.О. Масліков.- Наукові праці Національного університету харчових технологій. —-2015. - Т. 21, № 5. - С. 208-210.

4. Холодильная техника и технология : учебник / С.А. Большаков, В.Ф. Лебедев, А.В. Локтев, А.В. Руцкий. — Москва : ИНФРА, 2000. -286 с.

5. Большаков С.A. Холодильная техника и технология продуктов питания : учебник / С.А. Большаков. - Москва : Издательский центр «Академия», 2003. - 304 с.

6. Буянов О.Н. Кинетика вымерзания воды при замораживании сыров / О.Н. Буянов, И.В. Буянова. - Техника и технология пищевых производств. - 2015. - Т. 39, № 4. C. $14-18$.

7. Сидоренко Ю.И. К вопросу прогнозирования сроков хранения. (годности) продовольственных товаров / Сидоренко Ю.И., Гурьева К.Б. — 2017 [Електронний ресурс]. Режим доступу : http://www.rosreserv.ru/Konsultativnij_sovet/Obmen_opitom/ K_voprosu_prognozirovanija_srokov_hranen. 